YAK (552.5+551.24):0.02]:553.98.41

\title{
Т.А. Мельниченко
}

\section{КОМПАЕКСУВАННЯ АІТОЛОГІЧНОЇ І ТЕКТОНІЧНОЇ ІНФОРМАЦІЇ ПРИ РОЗВ'ЯЗАННІ ЗАААЧ НАФТОГАЗОПОШУКОВИХ ПРОБАЕМ}

\section{T.A. Melnichenko}

\section{INTEGRASION OF LITOLOGICAL AND TECTONIC INFORMATION FOR THE DECISION OF TASKS OF SEARCHING PROBLEMS ON AN OIL AND GAS}

\begin{abstract}
В публікації представлена літологічна та тектонічна інформація по Азово-Чорноморському регіону, Норвезькому морю, Мексиканській затоці, Тамані з метою демонстрації необхідності комплектування інформації, отриманої геофізичними, ^ітолого-стратиграфічними, геохімічними методами досліАження Аля виАілення основних позитивних критеріїв пошуку нафти і газу. Аля покращення розв'язання нафтогазопошукових проблем в геології тектонічна та літологічна інформація може бути Аоповнена Ааними, отриманими методом Аистанційного зондування Землі, який використовується в світовій практиці Аля виявлення нафтових плям, виходів газу на морській поверхні та ін.

Ключові слова: поклади нафти та газу, літологічні і тектонічні критерії, геолого-геофізична інформація, дегазація, флюїди.
\end{abstract}

This publication shows the lithological and tectonic information on the Azov-Black Sea region, the Norwegian Sea, Gulf of Mexico, Taman purpose of showing the need for combining information obtained by various methods of research (geophysical, lithological, stratigraphic, geochemical, etc.) to highlight the main positive criteria search for oil and gas. To improve the resolution of problems in oil and gas geology and tectonic lithologic information may be supplemented by data obtained by remote sensing, used in world practice for detecting oil spills, gas outputs on the sea surface and others.

Key words: deposit of oil and gas, litological and tectonic criteria, geology-geophysical information, degassing, fluids.

\section{ВСТУП}

ОАним з важливих показників економічного Аобробуту держави у сучасному світі є саме ступінь їі енергетичної незалежності. Нарощування в^асного енергетичного потенціалу в кожній країні привело до інтенсивного освоєння як мінеральних ресурсів, так й інших типів енергетики - AЕС, ГЕС, а також екологічно безпечних приладів, що виробляють енергію із сонячної, вітряної активності тощо.

За останні роки загострилася криза енергетичного забезпечення України власними ресурсами. ЗавАяки новим технологіям АосліАжуються та виАобуваються нетрадиційні вуглеводні (ВВ). Ао них відносять бітуміносні піски, метан вугільних пластів (сланцевий газ та нафта), газові гідрати. ПоклаАи останніх зосереАжені в Світовому океані (Ао 98\%) і мише 2\% знаходяться в зоні вічної мерзлоти і в арктичних пустелях (Гожик та ін., 2005, Новое исследование..., 2013). Успіхів в освоєнні нетрадиційних поклаАів ВВ Аосягли США, Ае різке зростання обсягів бурових робіт привело Ао збільшення видобутку сланцевого газу і сланцевої нафти. Видобуток сланцевого газу зріс з 25 млрА м ${ }^{3}$ у 2005 р. Ао 140 млрА м³ у 2010 р., Аані вилобутку сланцевої нафти також вражають: якщо в 2005 р. він становив 5 млн т на рік, то в 2012 р. - близько 50 млн т. Таким чином, за останні сім років рівень видобутку ВВ з нетрадиційних Ажерел в США збільшився приблизно в 10 разів (Новое исследование..., 2013). В Україні перспективною в цьому плані є західна частина Аонецького вугільного басейну - поклади ВВ у щільних колекторах - відклаАах середнього карбону.

Переважну більшість гігантських промислових родовищ нафти і газу світу відкрито в межах морського басейну: на континентальному схилі, шельфі, материковій обмілині.

у Світовому океані проводяться активні пошуки та розвіАка покладів нафти і газу країнами всіх континентів (Європи, Азії, Америки, Австралії, Африки). Гігантські і надгігантські родовища успішно розробляються на шельфі Перської затоки - 11 153 м^н т нафти і 35400 млрА м 3 газу, віАкрито 75 нафтових і 12 газових морських родовищ. Найкрупнішим регіоном нафтогазодобування в світі стало Північне море, на його частку припаАає близько 24\% світового Аобутку нафти і газу. Тут нафту і газ видобувають з пісковиків Аевону, карбону, пермі, тріасу, юри, крейди, еоцену та памеоцену і верхньої крейди (Гожик та ін., 2005).

Але основним джерелом енергетичного забезпечення ^юАства поки що залишається мінерально-сировинна база традиційних покладів нафти та газу. Актуальними є дослідження перспективних об'єктів нафти і газу у морському середовищі (шельф, континентальний схил, западина моря). 
В Україні - це басейн Чорного моря (північнозахідний шельф, ЗахіАно- і СхіАно-Чорноморські запаАини, континентальний схил, прибережна частина) та Азовського моря.

Численні геофізичні та гіАрофізичні досліАження, проведені в Чорному морі за останні 20 років (акаА. НАН України Є.Ф. Шнюковим, акаА. НАН України В.І. Старостенком та ін., а також багатьма геолого-досліАними організаціями та інститутами), дозволили виявити дегазацію морського Ана, що проявляється в Аіяльності газового і грязьового вулканізму та у виділеннях газу з Ана моря.

Окрім геофізичних метолів морське сереАовище Аосліджують за Аопомогою супутникових технологій - радіолокаційна зйомка морської поверхні. Цей метоА Аозволяє виявляти нафтові об'єкти шляхом фіксування природних нафтових плям (сліків) на поверхні моря, які утворюються при спливанні природної нафти з роАовищ нафти.

В цій публікації розгляАається комплектування літологічної та тектонічної інформації як основи Аля розв'язання нафтогазопошукових проблем. Аітологічна інформація про досліАжуваний об'єкт вкмючає літолого-стратиграфічний аналіз - визначення мінерально-речовинного складу, віку поріА, повноти розрізу, фільтраційно-ємнісних властивостей (пористість, проникність та ін.).

Загалом, в Україні виділяють три нафтогазоносних регіони: схіАний, захіАний і півАенний.

1. Східний регіон - Аніпрово-Аонецька запаАина (ААЗ), Ае віАкрито понаА 200 родовищ нафти і газу. В межах північного борту ААЗ нафтогазоносними виявилися не лише віАклади палеозою, а й утворення кристалічного фундаменту Східно-Європейської платформи, з яких отримано промислові припливи ВВ на Хухрянській та Юліївській площах (Іванюта, 1998).

2. ЗахіАний регіон об'єанує Волино-Подільську, Передкарпатську, Карпатську, Закарпатську нафтогазоносні області. Загалом з 91 родовища регіону 21 - нафтове, чотири - нафтогазові, шість - нафтогазоконденсатні, 44 - газові, шість - газоконденсатні (Іванюта, 1998).

3. Південний регіон - акваторія Чорного та Азовського морів, Крим, ПередаобруАзький прогин (Ава нафтових родовища - СхіАно-Саратське і Жовтоярівське та близько 20 газових перспективних Аілянок). Загалом, з початку розробки у Південному нафтогазоносному регіоні видобуто близько 0,07 млн т нафти, понад 17 млрА м ${ }^{3}$ газу і 0,25 млн т газового конденсату (Іванюта, 1998).
При розв'язанні задач нафтогазопошукових проблем перш за все потрібно враховувати літологічні та тектонічні критерії нафтогазоносності і доАаткові геолого-геофізичні дані - геологічну будову, розломоутворення, буріння сверАловин, прямі спостереження тощо. Чим більше отримано комп^ексних даних з позитивними ознаками нафто- чи газоносності, тим більше шансів на виявлення покладів ВВ. Тому комплектування геологічної інформації, отриманої різними методами, дає перспективні прогнози.

В Чорноморському регіоні перспективи нафтогазоносності пов'язані з крейдовими віАклаАами, в яких відкрито газове родовище Шмідта (верхня крейда, маастрихт), спостерігаються чис^енні нафтогазопрояви, непромислові припливи газу на Голіцинському, ОАеському родовищах, на Каркінітській, Фланговій та Штильовій площах.

Незважаючи на циклічність осадконакопичення, існувала певна успадкованість седиментаційних умов упродовж раннього майкопу, що піАтвераЖується стабільністю просторового поширення алевролітово-піщаних літофацій (Григорчук та ін., 2009). Літолого-стратиграфічні досліАження (Іщенко, 2014) в акваторії Азовського та Чорного морів свіАчать про перспективи нафтогазоносності крейдового породного комплексу. Породи-колектори альбу мають сереАні та низькі ємнісні та фільтраційні властивості. Основні перспективи пов'язуються з теригенними колекторами (пісковиками та алевролітами), що віАносяться Ао теригенних колекторів III класу з середніми ємнісними та фільтраційними властивостями. Породи-колектори верхньокрейаового породного комплексу мають середні та низькі ємнісні та фільтраційні властивості. Позитивними ємнісними та фільтраційними властивостями характеризуються: карбонатні породи-колектори маастрихту та кампану, які належать до карбонатних колекторів III класу. Відкрита пористість колекторів за Ааними лабораторних АосліАжень керна коливається віА 4 до 17\%. Теригенні породи-колектори кампану та сеноману відносяться Ао теригенних колекторів II-IV класу. Означені типи колекторів переважають головним чином у віАкладах маастрихтського, кампанського та сеноманського ярусів і поширені в межах більшої частини акваторії північно-західного шельфу Чорного моря та акваторії Азовського моря. Передбачаються вони також на прикерченському шельфі Чорного моря. В межах північно-захіАного шельфу 
Чорного моря крейАові віАклаАи розкрито у 36 сверАловинах, а в Азовському морі - в чотирьох (Іщенко, 2014).

ВіАклади майкопського продуктивного комп^ексу поширені на більшій частині північнозахіАного шельфу Чорного моря, віАсутні лише в південно-західній частині в межах Кікійського піАняття й валу Губкіна. Потужність їх збільшується 3 півночі на південь і досягає максимальних значень у центральній частині Каркінітсько-ПівнічноКримського прогину. На південь Ао Каламітского валу вона різко зменшується, а потім зростає на південному схилі північно-захіАного шельфу Чорного моря, знову зменшуючись у бік ПівнічноЕвксинського розлому.

Отже, при отриманні мітологічної інформації з позитивними критеріями Аля розв'язання задач нафто- і газопошукових проблем необхіАно визначити мінерально-речовинний склаА та фільтраційно-ємнісні властивості поріА, провоАити літо- і біофаціальний аналіз, детальне досліАження геологічного розрізу, палеореконструкцію осадконакопичення.

Тектонічна інформація Аля нафтогазопошукових задач потрібна Аля визначення зон тектонічних порушень, тріщинуватості поріА, побуАови Аетальних 3D-моделей геологічної будови структур. Аетального вивчення потребують зони розломів як Аілянки активних геодинамічних процесів, що впливають на шляхи міграції вуглеводневих флюїдів у пастки.

В Азово-Чорноморському регіоні нафтогазові поклади спостерігаються переважно взАовж зон розломів субмериАіонального простягання та їх перетину з розломами інших напрямків. На північно-західному шельфі Чорного моря Методом Аистанційного Зондування Землі виявлено три системи тектонічних розломів - Аинамопари лінеаментів: ортогональну (північ - південь, захіА - схіА), косодіагональну (північ - північний схіА, північ - північний захіА), Аіагональну (північний захіА, північний схіА) (Гожик та ін., 2010). Численні геофізичні та геологічні АосліАження в Чорному морі Аозволи^и виявити його блокову структуру, яка обумовлена мериАіональними, широтними, Аіагональними глибинними розривними порушеннями, а контури блоків збігаються з розмірами склалчастих структур, в тому числі нафтогазоносних (Гожик та ін., 2010). Таким чином, важмивим критерієм пошуків покладів ВВ, що впливає на їх локалізацію, є зони розломів.
Грязьові вулкани за своєю внутрішньою будовою схожі на багатоповерхові родовища нафти і газу. Виверженнями грязьових вулканів можуть бути гази, вода, грязі, тверАі викиАи (уламкові породи). Ці вулкани називають ще «трубами дегазації", що виносять величезні маси флюїАів, формуючи на морському Ані (Ао 700 м) поклаАи газогідратів (Шнюков, Пасынков, 2013). В хімічному складі вулканів даного типу переважає метан 3 Аомішками етану та інших газів - гомологів метану, $\mathrm{CO}_{2}$, азоту тощо.

Про глибинне походження грязьових вулканів свіАчить підвищення значень концентрацій ртуті у воді поблизу Ана моря (Шнюков, Пасынков, 2013) в Азово-Чорноморському регіоні.

Аналізуючи геологічну будову грязьових вулканів (рис. 1, 2) можна сказати, що вони являють собою природні канали виходу флюїдів на поверхню. Коренева система вулканів за геофізичними Ааними Аосягає 5-7 км (у Туркменістані), а в Азово-Чорноморському регіоні знахоАиться на глибинах 9-11 км і доходить до мезоЗойського фУнАаменту.

У грязьовому вулкані Карабетова гора, який знаходиться на Таманському півострові, А.^. Собісевич із співавторами (Собісевич та ін., 2008) встановив зв'язок регіональної геодинаміки і флюїдної активності та просліакував шляхи міграції флюїдів 3 глибин 15-25 км Ао поверхні Землі (рис. 1).

В ЗахіАно-Чорноморській западині за глибинним сейсмічним зонауванням в зоні розвитку грязьового вулканізму (Шнюков та ін., 2013) зафіксовано границю Мохо на глибині 19 км (рис. 2). Понал сотні субвертикальних геологічних тіл, які пронизують весь осаАовий чохол віА фундаменту на глибинах 18-19 км Ао поверхні і охарактеризовані як грязьові вулкани, виявлені в межах південної частини Каспійського басейну (Шнюков та ін., 2013); вони є зонами виходу флюїАів з глибинним походженням.

Наведені геофізичні розрізи грязьових вулканів свідчать про глибинну міграцію флюї̈ів, що спостерігається на вулканах суші і на морі, та асоціюються $з$ сейсмічними каналами вихоау флюїАних потоків із значних глибин. НаприклаА, у Норвезькому морі були проведені тривимірні сейсмічні спостереження в північній частині структури Storegga Slide та виявлені структури флюїдного потоку, розташовані вертикально Ао залягання пластів, які назвали каналами (Hustoft S. et al., 2010), (рис. 3). 


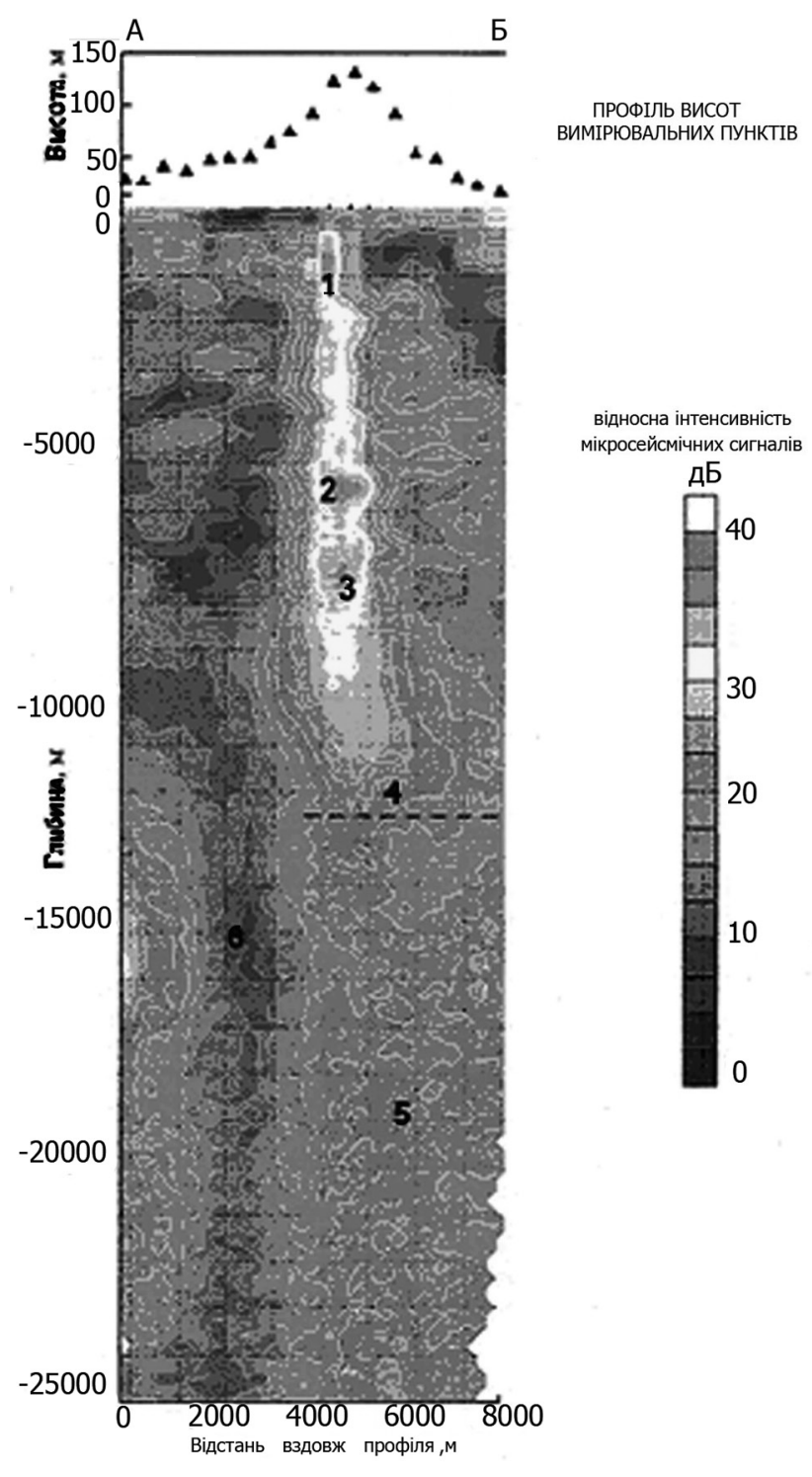

Рис. 1. Вертикальний геофізичний розріз вздовж профілю мікросейсмічного зондування грязьового вулкану Карабетова гора (Собисевич та ін., 2008).

1 - приповерхнева грязьовулканічна камера; 2, 3 - глибинні грязьовулканічні резервуари; 4 - область переходу Ао консолідованого фундаменту; 5 - глибинні флюїдопроникні структури; 6 - непроникні консолідовані породи.

Fig. 1. Geophysical vertical section along the profile macroseisic sensing mud volcano Karabetova mountain. 1 - subsurface mud-volcano camera; 2, 3 - mud-volcano deep reservoirs; 4 - the area of transition to a consolidated basement; 5 - fluid-entered deep structure; 6 - Consolidated impermeable rock (Sobisevich, et al., 2008).

В результаті аналізу сейсмічних розрізів встановлено, що вихіА флюїдів відбувається по цих каналах швиАко, подібно Ао вибуху, а сейсмічні канали мають еліпсоїдальну форму в плані. Азимут простягання еліпса дає можливість оцінити харак-

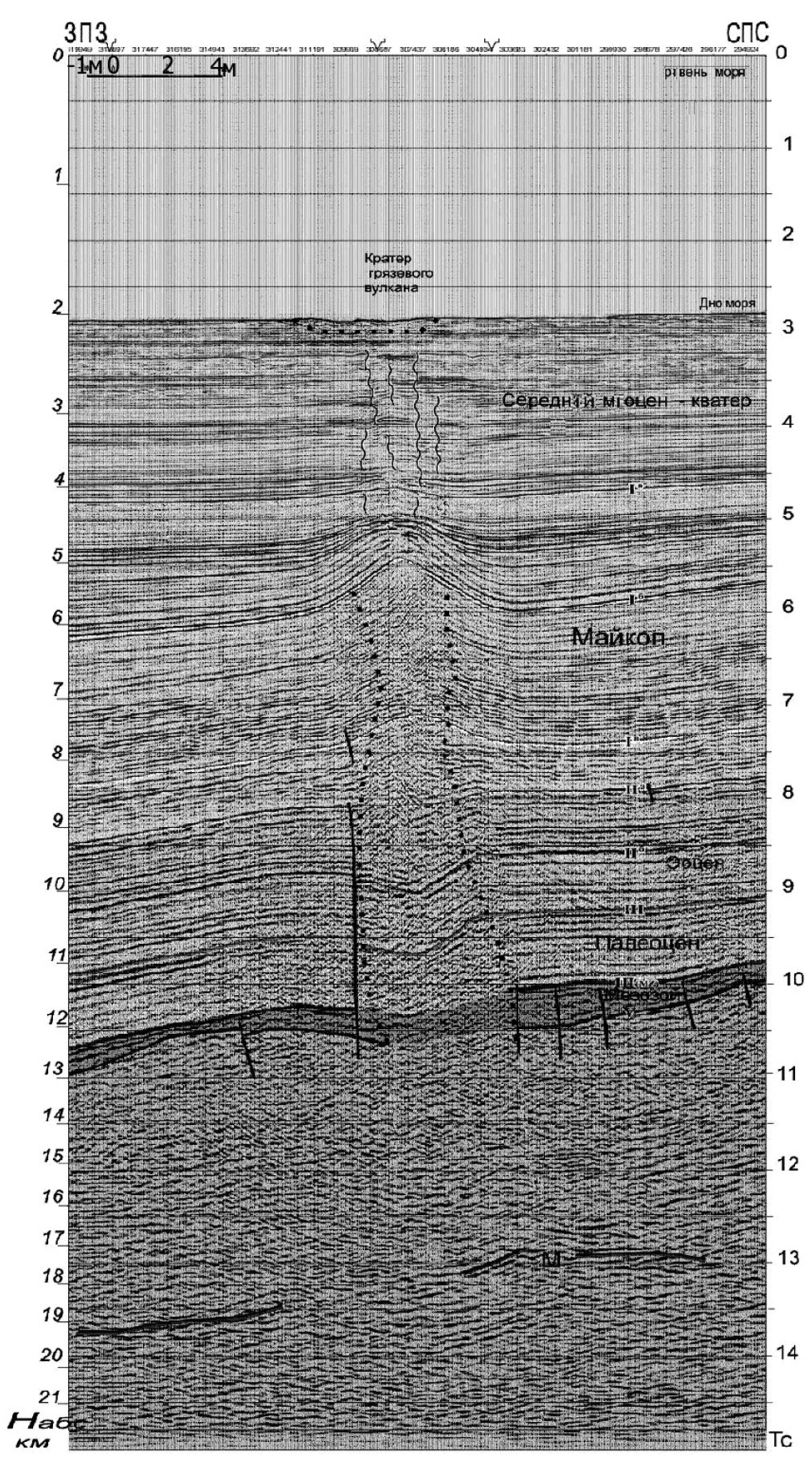

Рис. 2. Фрагмент часового сейсмічного розрізу, що характеризує глибинну геологічну обстановку в зоні грязьового вулкану $з$ координатами N 43,665 та E 33,155 (Шнюков та ін., 2013).

Fig. 2. Detail seismic time section that describes the deep geological situation in the area of mud volcano $\mathrm{N}$ $43,665^{\circ}$ та $\mathrm{E} 33,155^{\circ}$ coordinates (Shnukov et al., 2013).

тер формування каналів, Ае азимут простягання сейсмічного каналу наслідує існуючу структуру оточуючої кореневої зони. Основним висновком цього АосліАження $€$ встановлення просторового відношення між розломами та еліптичністю кана^ів міграції флюїАів, а довга вісь еліпса каналу віАображає азимут першого порядку тріщин у межах вертикальних каналів виходу флюїАів.

Механізмом Аля розвитку каналів і особливостей виходу флюїАного потоку на морське Ано $€$ нагнітання у породи великої кількості води піА 


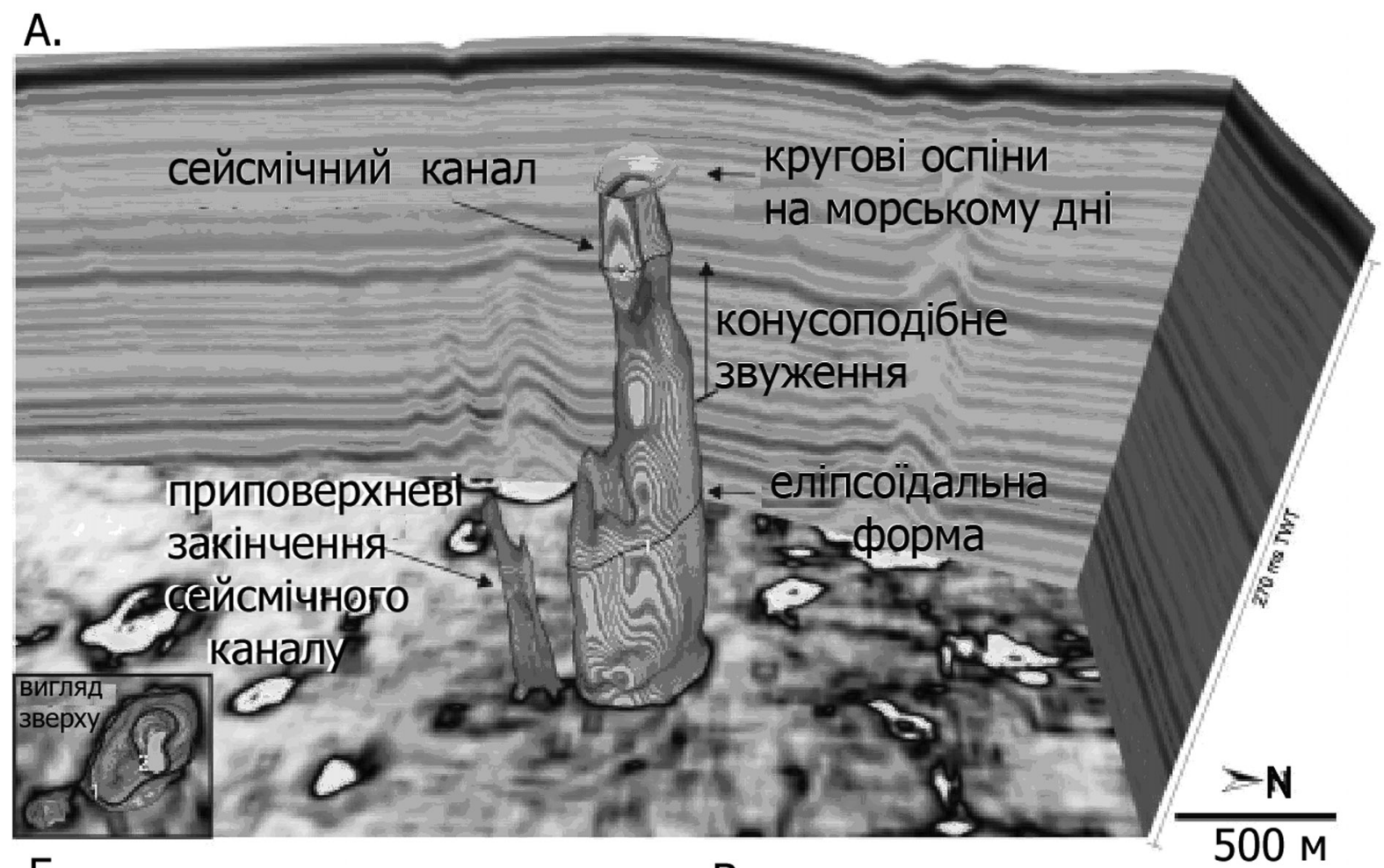

Б.

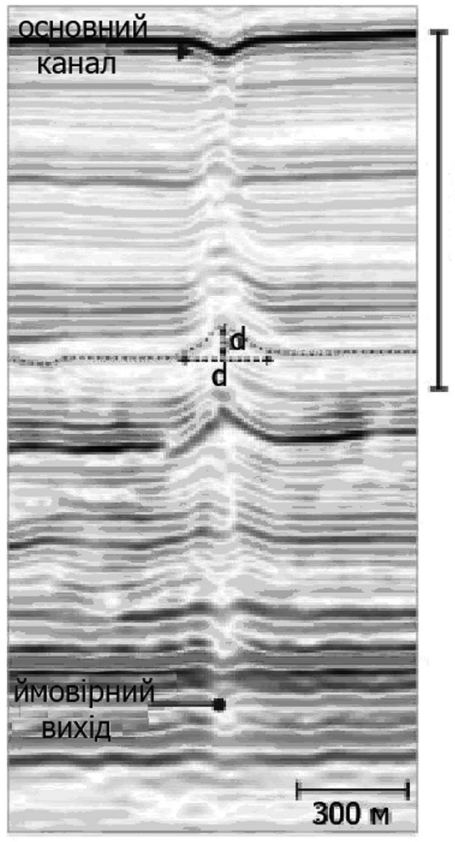

B.

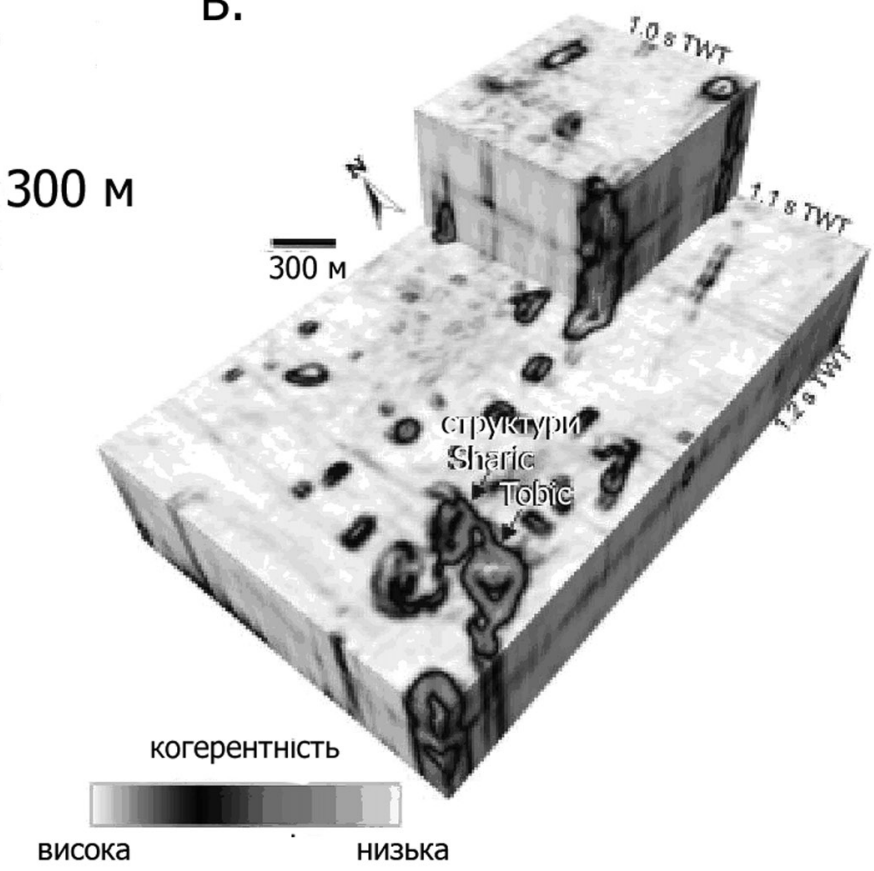

Рис. 3. 3D-зображення Авох показових каналів Норвезького моря на площі Nyegga , за (Hustoft S. et al., 2010). a - часовий розріз (270 м нижче Ана моря), що ілюструє сейсмічні аномалії каналу в межах послідовності акустично стратифікованих верхніх прошарків формації Naust; 6 - поперечний переріз типового каналу, що ілюструє визначення вершини кореня, діаметр (d) i зміщення вертикального відображення (а) віА каналу. в - куб послідовності, що ілюструє кругоподібну еліптичну форму кількох каналів , пов'язаних з газогідратами морського ана.

Fig. 3. (a) Volume rendering of a seismic coherency-cube shows the three-dimensional (3D) geometry of two representative chimneys at Nyegga. The time-slice ( $270 \mathrm{~ms}$ below seafloor) illustrates the high definition of seismic chimney anomalies within the hosting, acoustically wellstratified upper sequences of the Naust formation. (b) Cross-section of a typical chimney exemplifying our definitions of the top, apparent root, diameter (d) and vertical reflection offset (c) of a chimney. (b) The coherency cube exposes well the subcircular to elliptical geometry of a few chimneys (named) that are associated with near-seafloor gas hydrate, after (Hustoft S. et al., 2010). 
великим тиском, що спричиняє тріщини у пороАах, оточуючих канал, і швиАкий потік, поАібний Ао вибуху (Hustoft S. et al., 2010). Розподіл вільного газу в регіоні Nyegga Норвезького моря найімовірніше контролюється геометрією та ^ітологією покладів контуритів формації Naust (Рис.3) та їх віАстанню віА зони стабільності газогідратів. Високі сейсмічні амплітуди характеризують формацію Naust, яка залягає на 300 м глибше морського Ана. Сейсмічні 3D-дані свідчать про те, що сейсмічні канали пов'язані з природними оспінами (прогинанням) морського Ана, а призупинення витікання флюїдів вказує на те, що вільний газ знаходиться нижче зони стабільності газогідратів. Таким чином, Аілянки з оспінами на морському Ані свідчать про потужну міграцію вуглеводневих флюїАів, які можуть бути нафтогазоперспективними.

Радіолокаційні дослідження в Мексиканській затоці, проведені Minerals Management Service U.S. (M.M.S. U.S.) - Службою управління мінеральними ресурсами США у 2001 році, визначили, що за першими ознаками із запломбованої свердловини витікала нафта у серпні 1997 р. і в січні 1998 р., схожа за потоком витікання із природним просочуванням 3 морського Ана, що повинно формувати нафтову пляму на поверхні моря, яку чітко видно на радіолокаційній зйомці за віАповіАних умов вітру.

Аля точного виявлення появи нафтових плям і отримання правильної інформації про їх місце розташування в базу Ааних досліджень (Using ..., 2001) вк^ючено ще й місця розташування трубопроводів, нафтових платформ, шляхів руху суден у Мексиканській затоці. Результати Аослідження M.M.S. U.S. показали, що виявлені нафтові плями - це витікання з платформи Ship Shoal South block 349, і вони не є природними.

\section{РЕЗУЛЬТАТИ ТА ОБГОВОРЕННЯ}

Наведений метоА радіолокаційного АосліАження продемонстрував зАатність виявляти витоки нафти в море та визначати оптимальні фактори А^я покращення результатів по виявленню природних нафтових плям. Аля цього необхіАно виконати такі умови дослідження: 1) вибрати ідеальну тестову ділянку з документованими матеріалами, де точно вказані конкретні строки появи нафтових плям на поверхні моря; 2) мати точну характеристику плям: протяжність, інтенсивність витікання; 3) провести прямі спостереження і виміри просочування свердловини; 4) мати точ- ний прогноз погоди (швиАкість вітру, наявність опадів, хмарність тощо), якщо вітер має велику швидкість, то нафтові плями розриваються на Арібні та розчиняються у навколишньому водному середовищі і не фіксуються на радіолокаційному знімку; 5) врахувати положення нафтових трубопроводів, платформ, основних суднохіАних шляхів і батиметрії.

\section{ВИСНОВКИ}

На основі наведеного можна стверджувати: кожен метод геологічного АосліАження (геофізичний, літологічний, геохімічний, Аистанційного зонАування Землі та ін.) Аодає інформативність про АосліАжуваний об'єкт (поклаАи ВВ), що збільшує шанси при розв'язанні задач нафтогазопошукових проблем. Результати, отримані кожним з методів, Аопомагають встановити точні позитивні критерії пошуків у різних регіонах.

Комплектування літологічної та тектонічної інформації $€$ важливим Аля виділення основних позитивних критеріїв пошуків.

Ознакою нафтогазоносності на морі $€$ потужні виходи флюїдів на морському Ані, Аіяльність газового і грязьового вулканізму, газові виділення (газові факели), утворення газогідратів і нафтових плям на поверхні моря. Цікавим $є$ той факт, що гігантські і налгігантські родовища нафти і газу відкрито саме у Світовому океані, що вказує на перспективність пошуків цих корисних копалин у морському середовищі і прилеглій Ао нього території.

Геологічна інформація, отримана за різними методами Аослідження, є Аодатковою ланкою в ланцюгу оцінки перспектив відкриття роАовищ нафти і газу. За результатами кожного 3 методів можна визначити критерії Аля пошуків ВВ. За геофізичними методами досліджують фізичні властивості поріА у свердловинах, виявляють канали виходів флюїАів, фіксують глибинну будову об'єктів тощо. За літологостратиграфічним методом визначають мінера^ьний склаА та фільтраційно-ємнісні властивості (пористість, проникність) поріА. Аерокосмічними методами геологи фіксують ознаки нафтогазоносності: нафтові плями на поверхні моря, виходи газу, та ^інеаментні зони та інші геологічні структури.

Комплектування літологічної та тектонічної інформації в геології $€$ обов'язковою умовою Аля перспективи виявлення нафтогазоносних об'єктів. У цьому випаАку потрібно вра- 
ховувати дані всіх методів по Аосліджуваному об'єкту: геофізичного - акустичний каротаж, гамма-каротаж, сейсмофаціальний аналіз; ^ітолого-стратиграфічного - ^іто- і біофаціальний аналізи; геохімічного - мікро- і макроскопічного, рентгеноструктурного аналізів; геологічного -

\section{REFERENCES}

Gozhik P.F., Krayushkin V.A., Klochko V.P., Presence of oil and gas in the world continental slope. 2005, Geol. journal № 1, pp. 7-22. (In Ukrainian).

Gozhyk P.F., Bagriy I.D., Voitsytskyi Z.Ya., Gladun V.V., Maslun N.V., Znamenska T.O., Aks'om S.D., Kliushyna G.V., Ivanik O.M., Klochko V.P., Mel'nichouk P.M., Paliy V.M., Tsiokha O.G. Geological-structural-thermo-atmogeochemical substantiation of the petroleum presence in the Azov-Black sea aquatory, 2010, Kyiv, Logos, pp. 9-21. (in Ukrainian).

Grigorchuk K.G., Hnidets V.P., Balandyuk L.V. Lithology and sedimentogenesis Maikop deposits Karkinitsky-Northcrimean sedimentary-rock pool. Art. 2. Early Maikop. The geological paleo-oceanography and sedymentolitoh genesis. Geology and Geochemistry of Combustible Minerals. 2009, № 2 (147), pp. 71-83. (in Ukrainian).

Ivaniuta M.M. Atlas of oil and gas in Ukraine. V.6. South oil and gas region. 1998, Lviv: Centre Europe, 224 p. (in Ukrainian).

Ishchenko I.I. Assessment of hydrocarbon potential of Cretaceous rocks complex of Ukrainian Black and Azov seas sector with lithologic and stratigraphic opinions. 2014, Geol. journal № 1 (346), p.p 43-53. (in Ukrainian).

Sobisevich A.L., Gorbatikov A.V., Ovsyuchenko A.N. Deep structure of the mud volcano of Mount Karabetovoy. 2008, Reports of the Academy of Sciences, № 4, pp.542-546.

Shnyukov E.F., Kobolev V.P., Pasinkov A.A. Gas volcanism Black Sea. 2013, Kiyev: Logos, 384p. (in Russian).

Hustoft S., Bunz S. and Mienert J. Three-dimensional seismic analysis of the morphology and spatial distribution of chimneys beneath the Nyegga pockmark field, offshore mid-Norway. Department of Geology, University of Tromsø, Tromsø, Norway. The Authors Journal Compilation r Blackwell Publishing Ltd, European Association of Geoscientists \& Engineers and International Association of Sedimentologists. 2010. - Vol. 22, p.p. 465-480.

Using Satellite Radar Imagery to Detect Leaking Abandoned Oil Wells on the U.S. Outer Continental Shelf. [Електронний ресурс] Advanced Resources International, Incorporated 1110 North Glebe Road, Suite 600 Arlington, Virginia 22201 U.S.A. - 2001. - http://www.bsee.gov/Technologyand-Research/Oil-Spill-Response-Research/Reports/300399/355AA/. структурно-тектонічний аналіз, узагальнення геомогічних Ааних.

ЗавАяки новим технологіям 3'являється все більше нових методів АосліАження, за Аопомогою яких отримують Аодаткову інформацію Аля пошуків.

Гожик П.Ф. Нафтогазоносність світового континентального схилу/ П.Ф. Гожик, В.О. Краюшкін, В.П. К^очко // Геол. журн. - 2005. - № 1. - С. 7-22.

Гожик П.Ф. Геолого-структурно-термоатмогеохімічне обгрунтування нафтогазоносності Азово-Чорноморської акваторії. 1. Теоретичні та прикладні засади пошуків вуглеводнів в Азово-Чорноморському секторі України за комплексом геолого-структурно-термоатмогеохімічних АосліАжень/ П.Ф. Гожик, І.А. Багрій, З.Я. Войцицький, В.В. ГлаАун, Н.В. Маслун, Т.О. Знеменська, С.А. Аксьом, Г.В. Клюшина, О.М. Іванік, В.П. К^очко, П.М. Мельничук, В.М. Памій, О.Г. Цьоха // Київ: Аогос. 2010. - С. 9-21.

Григорчук К.Г. Аітологія і седиментогенез майкопських відклаАів Каркінітсько-Північнокримського осадовопородного басейну. Ст. 2. Ранній майкоп. Геологічна палеоокеанографія та седиментолітогенез / К.Г. Григорчук, В.П. Гнідець, А.В. Баландюк // Геологія і геохімія горючих копалин. - 2009. - № 2 (147). - С. 71-83.

Іванюта М.М. Атлас родовищ нафти і газу України. Т.6. ПівАенний нафтогазоносний регіон/ гол. реА. М.М. Іванюта // Аьвів: Центр Європи. 1998. - 224 с.

Іщенко І.І. Оцінка перспектив нафтогазоносності крейдового породного комплексу українського сектору акваторій Чорного та Азовського морів з літолого-стратиграфічних позицій / І.І. Іщенко // Геол. журн. - 2014. - № 1(346). C. $43-53$.

Собисевич А.А. Глубинное строение грязевого вулкана горы Карабетовой / А.А. Собисевич, А.В. Горбатиков, А.Н. Овсюченко // Аоклады Академии наук. - 2008. - № 4.C. 542-546.

Шнюков Е.Ф. Газовый вулканизм Черного моря/ Е.Ф. Шнюков, В.П. Коболев, А.А. Пасынков // Киев: Аогос, 2013, 384 c.

Hustoft S., Bunz S. and Mienert J. Three-dimensional seismic analysis of the morphology and spatial distribution of chimneys beneath the Nyegga pockmark field, offshore mid-Norway. Department of Geology, University of Tromsø, Tromsø, Norway. The Authors Journal Compilation r Blackwell Publishing Ltd, European Association of Geoscientists \& Engineers and International Association of Sedimentologists. 2010. - Vol. 22, p.p. 465-480.

Using Satellite Radar Imagery to Detect Leaking Abandoned Oil Wells on the U.S. Outer Continental Shelf. [Електронний ресурс] // Advanced Resources International, Incorporated 1110 North Glebe Road, Suite 600 Arlington, Virginia 22201 U.S.A. - 2001. - http://www.bsee.gov/Technologyand-Research/Oil-Spill-Response-Research/Reports/300399/355AA/. 
Novoe issledovanie Jenergeticheskogo centra biznesshkoly SKOLKOVO: "Netradicionnaja neft': stanet li bazhen vtorym Bakkenom?" Rogtec russian oil and gas technologies. 2013. https://goo.gl/VjY95o

Manuscript resived 29 November 2014; revision accepted 4 April 2015.
Новое исследование Энергетического центра бизнесшколы СКОЛКОВО: «Нетрадиционная нефть: станет ли бажен вторым Баккеном?" [Електронний ресурс] // Rogtec russian oil and gas technologies. - 2013. Режим доступу до pecypcy: https://goo.gl/VjY95o

Аержавна наукова установа "ВідАілення морської геології та осаАочного рудоутворення НАН України",

м. Київ, Україна. samara200@bigmir.net.

Рецензент: О.Ю. Митропольський

\section{Т.А. Мельниченко}

\section{КОМПАЕКСИРОВАНИЕ АИТОЛОГИЧЕСКОЙ И ТЕКТОНИЧЕСКОЙ ИНФОРМАЦИИ ПРИ РЕШЕНИИ ЗАААЧ НЕФТЕГАЗОПОИСКОВЫХ ПРОБАЕМ}

В публикации представлена литологическая и тектоническая информация по Азово-Черноморскому региону, Норвежском морю, Мексиканском заливе, Тамани с целью демонстрации необходимости комплексирования информации, полученной разными методами исследования (геофизического, митолого-стратиграфического, геохимического и др.) Аля выделения основных положительных критериев поиска нефти и газа. Аля улучшения решения нефтегазопоисковых проблем в геологии тектоническая и литологическая информация может быть дополнена данными, получены методом Аистанционного зонАирования Земли и используется в мировой практике Аля обнаружения нефтяных пятен, выходов газа на морской поверхности и ар.

Ключевые слова: залежи нефти и газа, митологические и тектонические критерии, геолого-геофизическая информация, Аегазация, флюилы. 